\title{
Bat casualties on a road crossing a mosaic landscape
}

\author{
Grzegorz Lesiński • Anna Sikora • Adam Olszewski
}

Received: 17 December 2009/Revised: 9 June 2010 / Accepted: 11 June 2010 /Published online: 24 June 2010

(C) The Author(s) 2010. This article is published with open access at Springerlink.com

\begin{abstract}
A year-round study was conducted on a $16.6-\mathrm{km}$ road section crossing Kampinos National Park near Warsaw (central Poland). We found 61 road-killed bats belonging to seven species. The most abundant were: Nyctalus noctula, Plecotus auritus, and Barbastella barbastellus. Bats were found between the middle of April and the end of October with peaks in July/August and October. The density of bat casualties differed slightly in various habitats surrounding the road-lower values than expected were found only for windbreaks and bushes. The prediction that low-flying species are killed more frequently was not confirmed - the most abundant $N$. noctula usually flies at heights over $10 \mathrm{~m}$ above the ground. N. noctula, Myotis nattereri, and Pipistrellus nathusii were killed more frequently while Eptesicus serotinus less frequently than could be expected from the frequency with which they were captured in mist-nets on forest lanes.
\end{abstract}

Communicated by C. Gortázar

G. Lesiński $(\bowtie)$

Department of Functional Food and Commodity,

Warsaw University of Life Sciences-SGGW,

Nowoursynowska $159 \mathrm{C}$,

02-787 Warsaw, Poland

e-mail: glesinski@wp.pl

A. Sikora

Student Scientific Group,

Interdisciplinary Department of Environmental Protection,

Warsaw University of Life Sciences-SGGW,

Nowoursynowska $159 \mathrm{C}$,

02-787 Warsaw, Poland

e-mail: a.b.sikora@wp.pl

\section{A. Olszewski}

Kampinos National Park,

Tetmajera 38,

05-080 Izabelin, Poland

e-mail: ad.ol@wp.pl
Keywords Chiroptera - Mortality · Road traffic · Phenology $\cdot$ Landscape structure $\cdot$ Central Europe

\section{Introduction}

Bats are rarely found as road casualties (Hodson 1960; Seibert and Conover 1991; Bartoszewicz 1997; Slater 2002; Smith and Dodd 2003; Coelho and Kindel 2008; Glista and De Vault 2008; Gryz and Krauze 2008). Nevertheless, as bats are much less abundant than many other vertebrates, killing by vehicles could be an important source of their mortality. Only few major studies focused on bats as road casualties (Rackow and Schlegel 1994; Kiefer et al. 1994/ 1995; Haensel and Rackow 1996; Lesiński 2007; Gaisler et al. 2009) supplemented by several short notes (i.e., Lesiński and Gwardjan 2001; Dikiy and Srebrodolska 2006). We are still not able to predict exact sites where bats may be particularly threatened or the species that may be at highest risk.

Some data indicate that young individuals and species usually flying at a lower height are killed more frequently (Haensel and Rackow 1996; Stratman 2006; Lesiński 2007). Depending on their foraging strategies, different bat species may be differently impacted by the fragmentation of habitats by a network of motorways (Kerth and Melber 2009). Also, linear landscape elements and their connection to roads play an important role in concentrating the risk of road kills (Lesiński 2007, 2008). The results published so far are not fully consistent. Species composition of bat road casualties markedly differs between roads. These differences are partly due to the structure of local bat assemblages, but this factor cannot completely explain the observed variation.

There is a need to conduct more studies on bat mortality on roads in various regions and landscapes. The aim of this 
paper was to find out which species are threatened by road traffic in a mosaic landscape containing forests, windbreaks, open, and built-up areas. Our goal was to determine the role of habitat structure along the road in distributing the risk of collision and to check the expectation that species flying at a lower height and young individuals are killed relatively more frequently. It was also expected that after renovation, the road section under study could be more dangerous to bats.

\section{Material and methods}

The census was done on $16.6 \mathrm{~km}$ of a one-lane 7 -m wide road No. 579 dividing Kampinos National Park into two approximately similar parts: eastern and western. Occurring on each side of the road are $1.2-\mathrm{m}$ wide roadsides and ditches. The study was carried out after renovation that took place in 2007 (the road was resurfaced and slightly widened). Both sides of the road plus roadsides and ditches were inspected once a week from 13 July 2008 to 28 June 2009 (in total, 51 surveys done in morning hours). In the period of April-October, the road was surveyed on foot (southern $10 \mathrm{~km}$ ) and by car, in two-person team-driver and researcher (northern $6.6 \mathrm{~km}$, car speed $15 \mathrm{~km} / \mathrm{h}$ ), in the period November-March exclusively by car. The traffic on the road section under study was relatively intensive - on June 26, 2009 between 21.00 and 22.00, there were 295 vehicles $/ \mathrm{h}$ (ca. 20\%, large lorries).

Kampinos National Park $(38,548.33$ ha, forest cover $73 \%$ ) is situated close to the capital of Poland-Warsaw. This area is also protected in the Natura 2000 network. In a $2-\mathrm{km}$ belt on both sides of the road under study, the area covered by forests constituted $71 \%$, windbreaks and bushes, 3\%; built-up area, 4\%; meadows and pastures, $15 \%$; and arable fields or wastelands, $7 \%$. Within forests, coniferous tree stands (38\%) and mixed tree stands (39\%) were abundant, and pure deciduous tree stands only $23 \%$. An average age of tree stands was 51 years (up to 60 years, $40 \%$; $61-100$ years, $45 \%$; and over 100 years, $15 \%$ ). The percent of the total section of the road bound by each of the habitat types was: $39 \%$ for windbreaks and bushes; $28 \%$ forests, $21 \%$ built-up area; and $12 \%$ open area.

Bats were identified to the species level mainly on the basis of external features with the help of the keys by Pucek (1981) and Dietz and von Helversen (2004). Additionally, if possible, sex and age were noted-from July to the beginning of September, young individuals in the first year of their life were recognized from adults by not fully ossified joints in the wing bones. Each place with a bat road kill was marked on the map, including the side of the road. All dead bats were removed from the road. To determine the percentage of bats within all casualties, other dead vertebrates were also noted.

Bat netting was performed in July, August, and September on forest lanes in the study area. Two nets per one point were used and monitored during the whole night. Only sites situated up to $5 \mathrm{~km}$ from the road were selected. This distance was chosen because most European bat species can fly several kilometers from roosting sites to foraging areas, even the relatively sedentary Eptesicus serotinus (Hutterer et al. 2005) - up to $11 \mathrm{~km}$ (Catto et al. 1996). A total of 188 individuals were caught at 17 netting points.

Proportions were compared by using $\chi^{2}$ test (with Yates correction if at least one number was lower than 10). The adopted significance level was 0.05 .

\section{Results}

Seven species of bats were found as road casualties with Nyctalus noctula and Plecotus auritus being the most abundant (together, over $50 \%$ of the total number; Table 1). In the sample of dead vertebrates (881) or, separately, mammals (314), bats (61) constituted, $6.9 \%$ and $19.4 \%$, respectively. There were more males (20) than females (seven) among those sexed, but the difference from the expected 1:1 sex ratio was statistically not significant $\left(\chi^{2}=\right.$ 2.3 $d f=1, P=0.13)$. Juveniles were present only during a half of the bat-flying activity period. Approximately one third of individuals belonged to three species ( N. noctula,
Table 1 Species, sex, and age structure of bats killed on the road under study (sex or age was possible to determine only for a limited number of individuals)

\begin{tabular}{lcccccc}
\hline Species & Number & Percent & ふふ & †+ & Adults & Juveniles \\
\hline N. noctula & 18 & 31.6 & 5 & 0 & 4 & 5 \\
P. auritus & 14 & 24.6 & 5 & 3 & 7 & 0 \\
B. barbastellus & 10 & 17.5 & 5 & 1 & 1 & 0 \\
M. nattereri & 6 & 10.5 & 2 & 1 & 0 & 2 \\
E. serotinus & 5 & 8.8 & 2 & 0 & 2 & 1 \\
P. nathusii & 3 & 5.3 & 1 & 1 & 2 & 0 \\
N. leisleri & 1 & 1.8 & 0 & 1 & 1 & 0 \\
Not determined & 4 & - & 0 & 0 & 0 & 0 \\
\hline
\end{tabular}


Fig. 1 Number of bat road casualties noted throughout a year

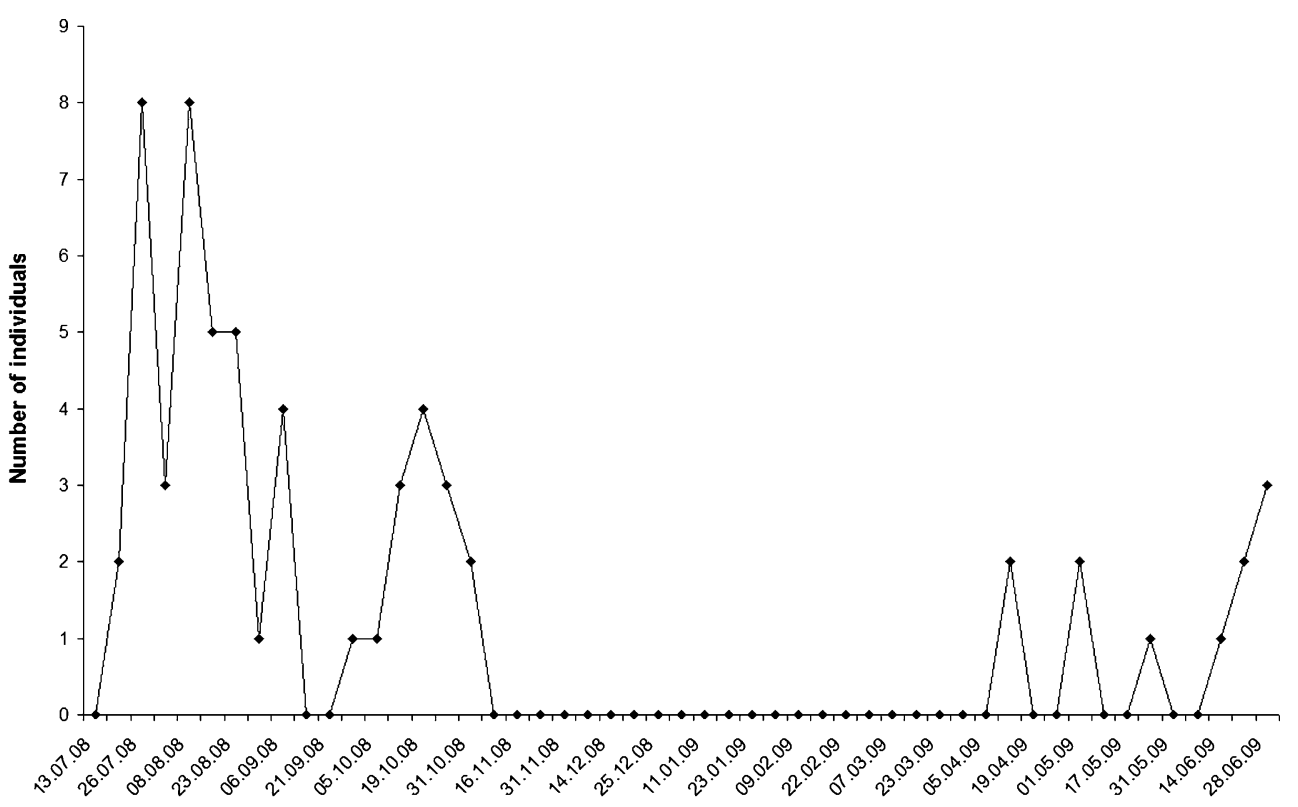

Pipistrellus nathusii, Nyctalus leisleri) which possess two young per two adults, and two third - only one young per two adults. Therefore, the expected ratio is about four adults per one juvenile. This ratio in the bat road casualties in which the age was determined was 17:8 and did not differ significantly from the expected one $\left(\chi^{2}=0.4, d f=1, P=0.52\right)$.

Bats were found between April 11 and October 31. Two distinct peaks of bat road kills were noted: first in the end of July and August and second (lower) in October (Fig. 1). Mean density of bat road kills per $1 \mathrm{~km}$ and year was 3.6, on the section crossing built-up area, 5.7; forest, 4.9; open area, 4.0; and windbreaks and bushes, 1.5 .

A statistically significant difference between the proportion of bats killed in each habitat type and the proportion of the road bound by this habitat type was only revealed in the case of windbreaks and bushes (lower number of bat road kills than expected; Table 2). The relation of bat casualties to linear landscape elements was weak, but two small clusters occurred near the villages Kiścinne and Kępiaste. It is also

Table 2 Observed proportions of the number of bats killed in each habitat to the number of bats in remaining habitats and expected proportion resulting from the length of the road crossing a given habitat to the length of the road crossing remaining habitats

\begin{tabular}{lrrl}
\hline Habitat type & Observed & Expected & $\begin{array}{l}\text { Difference: } \chi^{2}, \\
d f=1\end{array}$ \\
\hline Forest & $23: 38$ & $17: 44$ & $1.3, P=0.25$ \\
Windbreaks and bushes & $10: 51$ & $24: 37$ & $\mathbf{8 . 0}, \boldsymbol{P}=\mathbf{0 . 0 0 5}$ \\
Open area & $8: 53$ & $7: 54$ & $0.0, P=1.00$ \\
Built-up area & $20: 41$ & $13: 48$ & $2.0, P=0.15$ \\
\hline
\end{tabular}

Statistically important differences in bold worth noting that eight road kills of $N$. noctula were found in the forest situated in the south, and most individuals of $B$. barbastellus were found far from forests (Fig. 2).

The two most abundant species ( $N$. noctula and $P$. auritus) were killed mostly in summer, while B. barbastellus in autumn and E. serotinus, P. nathusii, and N. leisleri in spring. More than a half of road casualties (32) occurred in July and August (Fig. 3).

We made a comparison between the structure of the bat assemblage living in the forest of the study area and bats killed on the road. This analysis could indicate species of higher or lower risk of collisions. The bat species that were most abundant in mist nets on forest lanes (E. serotinus, $B$. barbastellus, $P$. auritus, and $N$. noctula) were also frequently killed by vehicles. The highest and statistically significant difference was noted for $N$. noctula, Myotis nattereri, and $P$. nathusii, killed by cars more frequently than expected, and E. serotinus, killed less frequently than expected (Table 3).

\section{Discussion}

The percentage of bats in the sample of vertebrates killed on the road under study $(6.9 \%)$ was relatively high. Usually, their share is much lower than $1 \%$, i.e., in Great Britain: 0.2-0.3\% (Hodson 1960; Slater 2002), the USA: 0.1-0.5\% (Seibert and Conover 1991; Smith and Dodd 2003; Glista and De Vault 2008), and Poland: 0.1-0.2\% (Bartoszewicz 1997; Gryz and Krauze 2008). Sometimes, they are absent, even in large samples of vertebrates (Clevenger et al. 2003; Hell et al. 2005; Najbar et al. 2006). Moreover, the mean density of bat casualties noted 


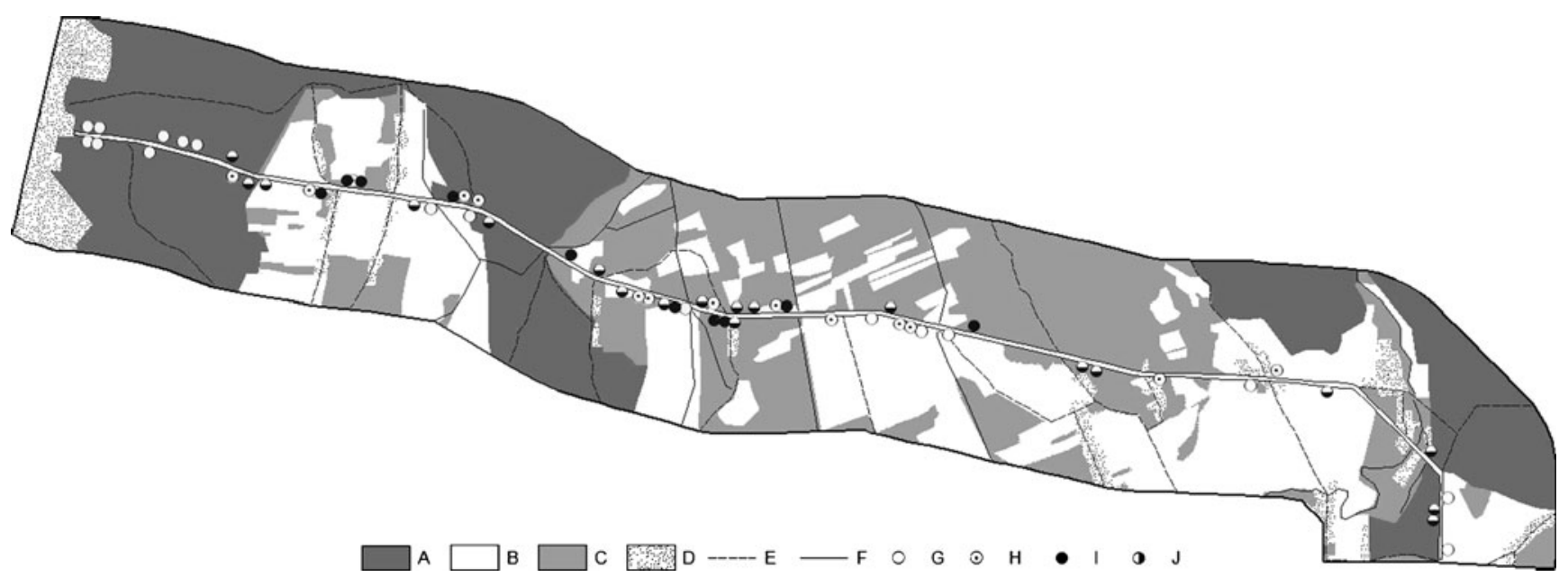

Fig. 2 Distribution of sites where dead bats were found on the road section under study; A forests, B open areas, $\mathbf{C}$ windbreaks and bushes, D built-up areas, E roads, $\mathbf{F}$ channels, $\mathbf{G}$ N. noctula, $\mathbf{H}$ P. auritus, I B. barbastellus, $\mathbf{J}$ other species

on the road under study was more than twice higher than the density recorded on a road situated closer to Warsaw, ca. $10 \mathrm{~km}$ away from the study area $(1.5 \mathrm{ind} . / \mathrm{km}$ and year; Lesiński 2007). The methods used in the two study areas were not fully compatible, mostly because of the shorter period of census in the latter (between May and October). One possible explanation of this difference could be a more abundant bat assemblage in habitats of Kampinos National Park. The highest difference between the two roads was found in a built-up area (5.7 vs. 0.7 ind. $/ \mathrm{km}$ and year), which suggests that villages of the study area are more important for bats than new suburban residential areas. On the other hand, relatively high values of two indices of bat mortality (percentage within vertebrates and density of road kills) could suggest that the road under study was especially dangerous for bats.

It should also be mentioned that the recorded bat casualties probably represent only a small portion of individuals killed. Some studies indicate serious underestimation of the number of recorded road kills (Svensson 1998; Slater 2002). Therefore, we cannot determine the real impact of road traffic on bat mortality. Still, as bats are relatively rarely present in the diet of predators, i.e., owls (Ruprecht 1979; Mikkola 1983; Obuch 1998), it is possible that collisions with vehicles are an important source of mortality of bats, especially in areas with a dense network of roads.

The period when dead bats were found on the roads in central Poland (from mid April to October) is shorter than
Fig. 3 Phenology of bat road kills in the study area

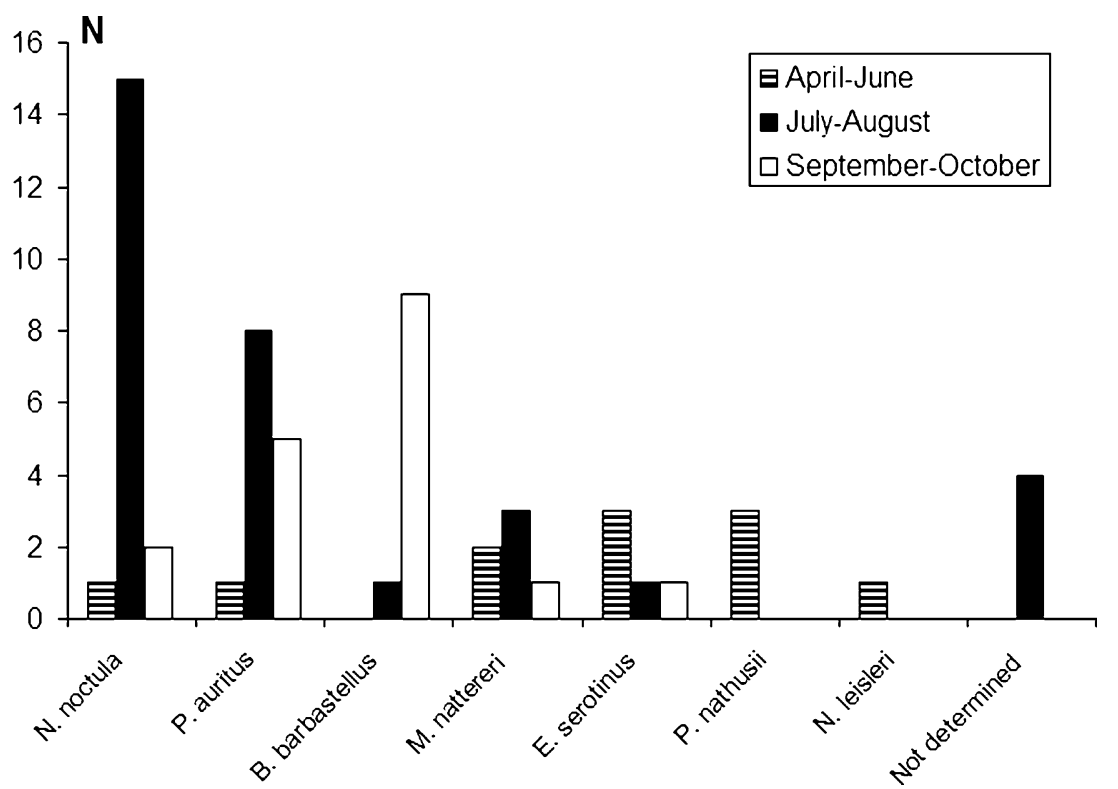


Table 3 Comparison of bats as road casualties and bats netted in forests

\begin{tabular}{lccl}
\hline Species & Road casualties & Caught in nets & $\begin{array}{l}\text { Difference } \\
(d f=1)^{\mathrm{a}} \chi^{2}, P\end{array}$ \\
\hline N. noctula & 18 & 15 & $\mathbf{2 0 . 9 0 , < 0 . 0 0 1}$ \\
P. auritus & 14 & 26 & $3.69,0.055$ \\
B. barbastellus & 10 & 30 & $0.08,0.777$ \\
M. nattereri & 6 & 7 & $\mathbf{4 . 0 3}, \mathbf{0 . 0 4 5}$ \\
E. serotinus & 5 & 83 & $\mathbf{2 2 . 2 7},<\mathbf{0 . 0 0 1}$ \\
P. nathusii & 3 & 0 & $\mathbf{6 . 1 4}, \mathbf{0 . 0 1 3}$ \\
Nyctalus leisleri & 1 & 1 & $0.00,0.954$ \\
Myotis myotis & 0 & 1 & $0.40,0.526$ \\
Myotis brandtii & 0 & 3 & $0.07,0.786$ \\
Myotis dasycneme & 0 & 13 & $2.90,0.089$ \\
Myotis daubentonii & 0 & 8 & $1.34,0.247$ \\
P. austriacus & 0 & 1 & $0.40,0.526$ \\
Total & 57 & 188 & - \\
\hline
\end{tabular}

Statistically important differences in bold

${ }^{\text {a }}$ Between proportions of the number of each species to the number of other species

in Germany (from March to November; Haensel and Rackow 1996), where the climate is warmer and bat activity lasts longer. But the presence of peak numbers of bat road kills noted in the study area in late summer and the beginning of autumn is typical for many roads (Haensel and Rackow 1996; Lesiński 2007, 2008; Gaisler et al. 2009). This phenomenon was explained by the higher abundance of bats in that period (young individuals begin to fly) and their intensive dispersal or movements to swarming areas (Lesiński 2008). It should be mentioned that the time of main risk of collisions might slightly change during the season. Rush hours remain approximately constant, but the time when bats emerge at dusk changes according to day length. The late occurrence of $B$. barbastellus, mostly outside forests, on the road under study could suggest that those individuals were killed during migration to winter roosts.

The results presented in this paper compared to the results from other roads, indicate high variability of species composition and frequency of each species among road casualties (Table 4). The most frequently killed bat species were E. serotinus in Lower Saxony, Germany (Rackow and Schlegel 1994), Pipistrellus pipistrellus s.l. in Germany as a whole (Haensel and Rackow 1996) and in France (Capo et al. 2006), Myotis daubentonii, M. nattereri, or N. noctula in Warsaw surroundings, Poland (Lesiński 2007, 2008 and this study), and Pipistrellus pygmaeus and P. nathusii in Czech Republic (Gaisler et al. 2009). The structure of local bat assemblages is the main source of this variation. In countries situated south and west from Poland, the

Table 4 The presence of the most abundant bat species as road kills in various regions of Europe

\begin{tabular}{|c|c|c|c|c|c|c|c|c|}
\hline Species & France $^{a}$ & $\begin{array}{l}\text { Germany, Lower } \\
\text { Saxony }\end{array}$ & $\begin{array}{l}\text { Germany, various } \\
\text { regions }{ }^{\mathrm{c}}\end{array}$ & $\begin{array}{l}\text { Czech } \\
\text { Republic }^{\mathrm{d}}\end{array}$ & $\begin{array}{l}\text { Poland, various } \\
\text { regions }\end{array}$ & $\begin{array}{l}\text { Poland, NE } \\
\text { Warsaw }^{\mathrm{f}}\end{array}$ & $\begin{array}{l}\text { Poland, E edge } \\
\text { of Kampinos } \\
\text { National Park }\end{array}$ & $\begin{array}{l}\text { Poland, central } \\
\text { part of Kampinos } \\
\text { National Park }{ }^{\mathrm{h}}\end{array}$ \\
\hline M. nattereri & 2 & 2 & 7 & 1 & 2 & 37 & 10 & 6 \\
\hline M. daubentonii & 14 & 4 & 17 & 19 & 9 & 1 & 53 & 0 \\
\hline E. serotinus & 0 & 15 & 35 & 4 & 12 & 0 & 3 & 5 \\
\hline P. pipistrellus s.l. & 47 & 13 & 83 & 42 & 0 & 0 & 0 & 0 \\
\hline N. noctula & 0 & 6 & 39 & 1 & 1 & 0 & 2 & 18 \\
\hline P. auritus & 2 & 2 & 25 & 0 & 13 & 6 & 25 & 14 \\
\hline B. barbastellus & 1 & 0 & 4 & 0 & 2 & 0 & 0 & 10 \\
\hline Other species & 27 & 7 & 71 & 37 & 11 & 1 & 14 & 4 \\
\hline Total $^{\mathrm{i}}$ & 93 & 49 & 281 & 104 & 50 & 45 & 109 & 57 \\
\hline
\end{tabular}

Most frequently killed are bolded

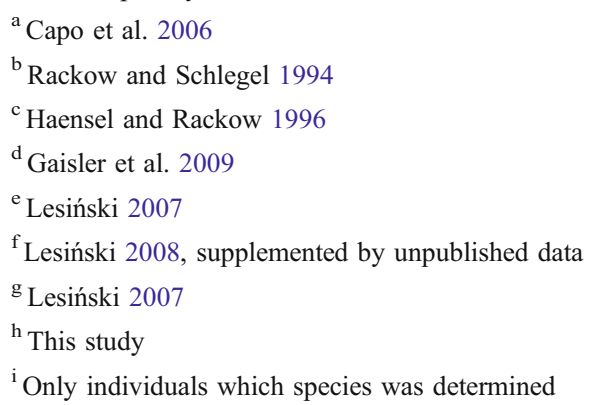


pipistrelle bats, especially P. pipistrellus or P. pygmaeus, are probably more abundant in bat assemblages. In Germany, France, and Poland, only P. auritus seems to be the most constant species among those killed relatively frequently (Haensel and Rackow 1996; Capo et al. 2006; Lesiński 2007; 2008, this study), while it was absent on the road between Brno and Vienna (probably it was not abundant in the bat assemblage; Gaisler et al. 2009).

An important role is also played by the structure of landscapes. Completely different results were reported for the road bordering the same forest complex but situated $10 \mathrm{~km}$ from the road under our study (Lesiński 2007). The most frequently killed species there- $M$. daubentonii was absent among bats found on the road crossing Kampinos National Park. The study of Lesiński (2007) was conducted in a landscape in which the road ran between wooded areas and a large river valley. This could explain intensive dispersal of water-connected bats (mostly M. daubentonii) between forest and river.

A crucial factor influencing the number of collisions with animals, especially flying species, could be the speed of vehicles and their size. Census done before renovation of the road under study did not show any bats within a sample of 1,600 vertebrates (Owadowska and Szpakowski 2005). At present, cars can go there with speed exceeding $100 \mathrm{~km} / \mathrm{h}$, and many large lorries have started to use the road also at night hours.

Prediction that individuals flying higher are killed less frequently (Stratman 2006; Lesiński 2007) was not confirmed on the road crossing Kampinos National Park. The most abundant species among road casualties $-N$. noctulais a typical high flying bat (usually over $10 \mathrm{~m}$ above the ground-Gebhard and Bogdanowicz 2004). Frequent occurrence of this species in our sample was probably due to the lack of space between the road and tree stands. Many individuals of $N$. noctula as well as other species commuted along forest lanes and flew directly into the road space. Moreover, the population of $N$. noctula in the forests of Kampinos National Park could be very abundant as was also revealed by a bat detector study (Lesiński et al. 2000). On no other road, $N$. noctula prevailed in the samples of bats killed by vehicles, but in Lower Saxony among 61 bats, six belonged to this species (Rackow and Schlegel 1994).

Species usually commuting by using forest lanes $-P$. auritus, B. barbastellus (Lesiński et al. 2007)—were frequent road kills. Some species flying higher and rarely using forest lanes ( $P$. pygmaeus, $P$. nathusii) seemed to be in the group of lower risk and seldom or never killed on the road under study. But in Germany and the Czech Republic, bats of the genus Pipistrellus were abundant as road casualties (Rackow and Schlegel 1994; Kiefer et al. 1994/ 1995; Haensel and Rackow 1996; Gaisler et al. 2009). This confirms the importance of landscape structure as a factor influencing the risk of bat collisions with vehicles. Most bats were probably killed while trying to cross the road. Nevertheless, it cannot be excluded that some individuals tried to forage over an asphalt surface which was warm in the summer evenings and attracted insects.

Also, the expectation that young individuals should prevail in the sample of bats killed by cars (Haensel and Rackow 1996; Lesiński 2007) was not supported by our results. Probably, the road in Kampinos National Park does not cross important routes of bat dispersal as it was for instance between forests and a river valley in the study of Lesiński (2007).

Netting on forest lanes gives information about the structure of local bat assemblages. However, we must remember that this method may underestimate the abundance of some species, rarely using lanes, e.g., Pipistrellus spp. or those highly connected to human settlements (Plecotus austriacus). Differences obtained between the results of netting and monitoring of the road casualties should be interpreted carefully. It is possible that fast flying $N$. noctula could be more vulnerable to collisions when it flies along forest lanes, contrary to slow flying and more connected to vegetation $P$. auritus or B. barbastellus. The fact that E. serotinus seems to avoid collisions is hard to explain. It cannot be excluded that bat species used to foraging along forest lanes (E. serotinus, P. auritus, and $B$. barbastellus) are more careful.

The results of this study support the opinion that road traffic could be a major source of bat mortality. Variability in species composition and proportions of each species on different roads result both from the structure of local bat assemblages and the landscape structure. Some species, i.e., $P$. auritus, are frequent road kills on many roads. The number of collisions seems to be strongly dependent on the speed of vehicles which is suggested by the absence of dead bats before the renovation of the road under study (Owadowska and Szpakowski 2005).

Acknowledgments Authors are grateful to Ewa Pełnia-Iwanicka, Jan Danyłow, Krystyna Sikora, Jan Sikora, Julia Dobrzańska, Małgorzata Płaczek, and Bartłomiej Popczyk for their help in the field work. Jan Danyłow, Maciej Fuszara, and Karolina Potocka helped us to improve English.

Open Access This article is distributed under the terms of the Creative Commons Attribution Noncommercial License which permits any noncommercial use, distribution, and reproduction in any medium, provided the original author(s) and source are credited.

\section{References}

Bartoszewicz M (1997) Mortality of vertebrates on the highway bordering on the Słońsk Reserve, western Poland. Parki Narodowe i Rezerwaty Przyrody 16(4):59-69, In Polish with English summary 
Capo G, Chaut JJ, Arthur L (2006) Quatre ans d'étude de mortalité des Chiroptères sur deux kilomèters routiers proches d'un site d'hibernation. Symbioses 15:45-46

Catto CM, Hutson AM, Racey PA, Stephenson PJ (1996) Foraging behaviour and habitat use of the serotine bat (Eptesicus serotinus) in southern England. J Zool, London 238:623-633

Clevenger AP, Chruszcz B, Gunson KE (2003) Spatial patterns and factors influencing small vertebrate fauna road-kill aggregations. Biol Conserv 109:15-26

Coelho IP, Kindel A (2008) Roadkills of vertebrate species on two highways through the Atlantic Forest Biosphere Reserve, southern Brazil. Eur J Wildl Res 54:689-699

Dietz C, von Helversen O (2004) Illustrated identification key to the bats of Europe. http://www.uni-tuebingen.de/tierphys/Kontakt/ mitarbeiter seiten/dietz.htm

Dikiy IW, Srebrodolska EB (2006) Casus of death of rare bat species on the roads in Prykarpattia (Lviv Region). Vestn Zool 40:114, In Russian with English summary

Gaisler J, Řehák Z, Bartonička T (2009) Bat casualties by road traffic (Brno-Vienna). Acta Theriol 54:147-155

Gebhard J, Bogdanowicz W (2004) Nyctalus noctula (Schreber, 1774)-Grosser Abendsegler. In: Niethammer J, Krapp F (eds) Handbuch der Säugetiere Europas, Band 4/II Fledertiere II. Aula, Wiesbaden, pp 607-694

Glista DJ, De Vault TL (2008) Road mortality of terrestrial vertebrates in Indiana. Proc Indiana Acad Sci 117:55-62

Gryz J, Krauze D (2008) Mortality of vertebrates on a road crossing the Biebrza Valley (NE Poland). Eur J Wildl Res 54:709-714

Haensel J, Rackow W (1996) Fledermäuse als Verkehrsopfer-ein neuer report. Nyctalus (NF) 6:29-47

Hell P, Plavý R, Slamečka J, Gašparík J (2005) Losses of mammals (Mammalia) and birds (Aves) on roads in the Slovak part of the Danube Basin. Eur J Wildl Res 51:35-40

Hodson NL (1960) A survey of vertebrate road mortality, 1959. Bird Study 7:224-231

Hutterer R, Ivanova T, Meyer-Cords C, Rodrigues L (2005) Bat migrations in Europe: a review of banding data and literature. Naturschutz und Biologische Vielfalt 28. Federal Agency for Nature Conservation, Bonn

Kerth G, Melber M (2009) Species-specific barrier effects of a motorway on the habitat use of two threatened forest-living bat species. Biol Conserv 142:270-279

Kiefer A, Merz H, Rackow W, Roer H, Schlegel D (1994) Bats as traffic casualties in Germany. Myotis 32:215-220
Lesiński G (2007) Bat road casualties and factors determining their level. Mammalia 71:138-142

Lesiński G (2008) Linear landscape elements and bat casualties on roads - an example. Ann Zool Fenn 45:277-280

Lesiński G, Gwardjan M (2001) Whiskered bat Myotis mystacinus and Brandt's bat $M$. brandtii as traffic casualties on roads in central Poland. Nietoperze 2:135-138, In Polish with English summary

Lesiński G, Fuszara E, Kowalski M (2000) Foraging areas and relative density of bats (Chiroptera) in differently human transformed landscapes. Z f Säugetierk 65:129-137

Lesiński G, Kowalski M, Wojtowicz B, Gulatowska J, Lisowska A (2007) Bats on forest islands of different size in an agricultural landscape. Folia Zoologica 56:153-161

Mikkola H (1983) Owls of Europe. T \& AD Poyser, Calton, 440 pp

Najbar B, Najbar A, Szuszkiewicz E (2006) Traffic mortality in selected groups of vertebrates on roads in the Zielona Góra region (W Poland). Chrońmy Przyrodę Ojczystą 62(6):56-66, In Polish with English summary

Obuch J (1998) The representation of bats (Chiroptera) in the diet of owls (Strigiformes) in Slovakia. Vespertilio 3:65-74, In Slovak with English summary

Owadowska E, Szpakowski P (2005) Animals killed on the road Kazuń-Leszno. Puszcza Kampinoska 3:11-13, In Polish

Pucek Z (1981) Keys to vertebrates of Poland: mammals. PWN, Warsaw, $367 \mathrm{pp}$

Rackow W, Schlegel D (1994) Fledermäuse (Chiroptera) als Verkehrsopfer in Niedersachsen. Nyctalus (NF) 5:11-18

Ruprecht AL (1979) Bats (Chiroptera) as constituents of the food of barn owls Tyto alba in Poland. Ibis 121:489-494

Seibert HC, Conover JH (1991) Mortality of vertebrates and invertebrates on an Athens County, Ohio, Highway. Ohio J Sci 91:163-166

Slater FM (2002) An assessment of wildlife road casualties - the potential discrepancy between numbers counted and numbers killed. Web Ecology 3:33-42

Smith LL, Dodd CK Jr (2003) Wildlife mortality on US Highway 441 across Paynes prairie, Alachua County, Florida. Fla Sci 66:128140

Stratman B (2006) Zur Kollisionswahrscheinlichkeit fliegender oder jagender Fledermäuse bei der Querung von Verkehrswegen. Nyctalus (NF) 11:268-276

Svensson S (1998) Birds kills on roads: is this mortality factor seriously underestimated? Ornis Svec 8:183-187 